Dhaka Univ. J. Biol. Sci. 23(1): 77-83, 2014 (January)

\title{
PARENTAL AND CHILDREN ATTITUDE TOWARD HOMEWORK
}

\author{
NAFIZA FERDOWSHI ${ }^{* 1}$ AND SHAHEEN IsLAM \\ Department of Educational and Counselling Psychology, University of Dhaka, \\ Dhaka-1000, Bangladesh
}

Key words: Parents, Children, Attitude, Homework

\begin{abstract}
A comparative analysis between parental and children's attitude toward homework for three grade levels (Grade-III, V and VII) reveals the importance of homework in educational experience. Two hundred sixty parents (140 mothers and 120 fathers) and 260 children (148 girls and 112 boys) of different schools in Dhaka city responded to parent and children forms of attitude toward homework questionnaire. Chi square value indicated common agreement between the children and the parents' attitude toward homework. Certain dimension of children's attitude differed for grade levels and gender. The study also focused on the effect of homework on family relationship and general attitude toward school.
\end{abstract}

\section{Introduction}

Education is an experience that has a formative effect on an individual's mind, character, or physical ability. All teaching-learning models consider homework as an essential aspect to bring qualitative changes in one's educational experience. Homework is defined as 'tasks assigned to students by school teachers that are meant to be carried out during non-school hours'(1). Like broader areas of education, people have divergent and cyclical attitudes toward homework(2). The way a person views something predisposes his/her tendency to behave or respond in a favorable or unfavorable manner to that particular thing(3). Hence, homework has been a perennial topic of debate about the necessity of homework in education. A number of studies have provided growing evidence of the usefulness of homework when employed effectively ${ }^{(4)}$. A review of over 60 research studies showed that, within limits, there is a positive correlation between the amount of homework done and student achievement ${ }^{(5)}$. The research synthesis also showed that too much homework could be extremely counter productive, causing students to "burn out".

Homework is considered important because it is at the intersection between home and school. It serves as a window through which parents can observe their children's education and express positive attitudes toward children and their education ${ }^{(6)}$. Hill and

*Author for correspondence: <nafizaf@student.uv.uio.no>. ${ }^{1}$ Present address: Department of Special Needs Education, University of Oslo, Norway. 
Tyson conducted a meta-analysis on the 50 existing research on parental involvement in middle school and found positive association with achievement, with the exception of parental help with homework ${ }^{(7)}$. Involvement that reflected academic socialization had the strongest positive association with achievement. The secondary school study found variables posited to predict homework completion at class and student level e.g., parent education, teacher feedback, self-reported grade, learning-oriented reasons for doing homework, homework interest, and homework management. It also found girls reported statistically significant higher scores in homework completion than boys ${ }^{(8)}$. The rate of homework completion is related to reinforcement. Hancock investigated that students, who received verbal praise from their professors, spent significantly more time for completing homework than students who received no verbal praise ${ }^{(9)}$.

Homework is an indispensable part of instruction in all schools of Bangladesh. Limited focus has been directed to consider its nature and extent for making it a beneficial learning experience. Homework resembles real life problem simulations and strengthens children's intellectual capabilities for next stage of learning. Increase understanding about parental and children viewpoint of homework at different grade levels can facilitate positive parental involvement in children's homework that will expect to improve parent-child relationship. This study can identify specific factors like reinforcement for homework that will help to enhance academic performance and educational standard. The present study investigated parental attitude towards homework and its influence on attitude towards school.

\section{Materials and Methods}

The participants of the present study consisted of 260 children from Grade-III, V, and VII and their parents taken from six schools of Dhaka city in Bangladesh. Purposive sampling was used to include those who consented to participate. One hundred forty mothers (53.95\%) and 120 (46.15\%) fathers participated in the study. Sample statistics on Table 1 show that greater number of respondents were girls and variation can be noted among grades. Majorities (55.4\%) of the respondents were first born and had more than two siblings. A notable amount of respondents with below average results were included and about $8 \%$ of children were living with single parent. Majority of the parents had education above secondary level.

Bangla version of parent and children form of attitudes to homework questionnaire were applied to collect data along with a demographic and personal information form ${ }^{(10)}$. Flyers with information about the research and consent letter addressing the parents were used.

Both the forms consist of 22 open and closed ended questions. Fourteen items concerning affective aspect and parental support were formatted in 5-point Likert scale. Responses varied from ' 1 ' for 'never' to ' 5 ' for 'always'. It included both negative and 
positive questions. Five items related to extent and nature of homework, relation with school, result etc. had structured responses. Rests three were open-ended questions focused on reasons, reward and punishment.

Table 1. Selected demographic variables (\%) of children.

\begin{tabular}{|c|c|c|c|c|c|c|c|c|c|c|}
\hline \multirow[t]{2}{*}{ Grades } & \multicolumn{2}{|c|}{$\begin{array}{l}\text { Gender } \\
(\%)\end{array}$} & \multicolumn{3}{|c|}{$\begin{array}{c}\text { Birth order } \\
(\%)\end{array}$} & \multirow{2}{*}{$\begin{array}{c}\text { Sibling } \\
(\%) \\
<3\end{array}$} & \multirow{2}{*}{$\begin{array}{c}\text { School } \\
\text { result }(\%)\end{array}$} & \multirow{2}{*}{$\begin{array}{c}\begin{array}{c}\text { Family } \\
\text { type }\end{array} \\
\text { Single } \\
\text { parent }(\%)\end{array}$} & \multicolumn{2}{|c|}{$\begin{array}{l}\text { Parental education } \\
\text { (< secondary level) }\end{array}$} \\
\hline & Boy & Girl & $\begin{array}{l}\text { First } \\
\text { born }\end{array}$ & $\begin{array}{l}\text { Later } \\
\text { born }\end{array}$ & $\begin{array}{l}\text { Middle } \\
\text { born }\end{array}$ & & & & $\begin{array}{c}\text { Mother } \\
(\%)\end{array}$ & $\begin{array}{c}\text { Father } \\
(\%)\end{array}$ \\
\hline Grade III & 29.5 & 21.6 & 63.1 & 9.2 & 27.7 & 26.1 & 19.9 & 12.3 & 27.7 & 7.7 \\
\hline Grade V & 43.8 & 29.7 & 57.0 & 15.1 & 28.0 & 25.1 & 47.6 & 12.9 & 34.4 & 23.7 \\
\hline Grade VII & 26.8 & 48.6 & 49.0 & 20.6 & 30.0 & 17.3 & 58.0 & 2.9 & 43.1 & 34.3 \\
\hline Total & 43.1 & 56.9 & 55.4 & 15.8 & 28.8 & 22.8 & 44.6 & 8.8 & 36.2 & 23.8 \\
\hline
\end{tabular}

The English version of both questionnaires was translated into Bangla. The focus of the translation was to maintain conceptual rather than literal meaning. Test-retest reliability on 75 children and 75 parents was measured over two weeks. Correlation coefficient for parent and children attitude scale were 0.81 and 0.69 , respectively.

Upon prior permission from the school authority the flyers explaining the purpose of the research and the importance of its findings were circulated to parents. Parents willing to participate signed a consent letter for allowing their children to be included in the study. Participants were assured regarding confidentiality and access of collected data. Questionnaires were distributed to the parents with written instruction. For children the questionnaires were administered individually during recess period at school. Filled in questionnaires were collected from the parents within one week. Turnover of questionnaires was $75 \%$.

\section{Results and Discussion}

The study found that, both children and parents reported homework as beneficial. 'Regular practice' was the foremost reasons for giving homework for both the groups. The second highest response for children was 'good result' (26.9\%) whereas for parents' it was 'to be attentive' (21.5\%). These were followed by other beneficial functions of homework such as 'to facilitate learning and development', 'to improve handwriting'. Though response of the parent did not differ by grade; but there were significant difference in children's response for grades (Chi square $=17.51, \mathrm{df}=8, \mathrm{p}<0.05$ ). Grade difference in response shows that the children become more aware of the benefits as they grow older. Research provides strong evidence that, when used appropriately, homework benefits student achievement through developing habits and attitude at early $\operatorname{grades}^{(4,11)}$. 
Though majority of the children across the grades agreed upon 'regular practice' (30.4 - $36.6 \%$ ) as leading reason for giving homework by teachers, only $6.2 \%$ children of grade 3 could see the benefit of homework for better learning and development purpose. Similarly fewer children of upper grades identified 'being attentive' as a reason for giving homework. The table 2 reveals favourable attitude of majority of parents and children towards homework. More than $50 \%$ of the parents and the children responded that children have to do homework every night and is 'neither easy nor difficult'; a great majority of both the groups agreed to the amount of homework as satisfactory, similarly above average respondents of both groups said that children complete the assigned homework. Significant differences in responses of the children were found on amount (Chi square $=16.941, \mathrm{df}=6, \mathrm{p}<0.05)$ and frequency of homework (Chi square $=13.620, \mathrm{df}$ $=6, \mathrm{p}<0.05$ ). Significantly more than 50 of the children except grade 5 agreed that they have to do homework every night and $23.7 \%$ of grade 5 children think that the teacher gives too much homework, as opposed to only $3.1 \%$ of grade 3 children. In relation to this finding sample statistic. Majority of lower grader (80.1\%) achieved average or above average score on test compared to higher grader (42.0\%). This result is also consistent with another global study that revealed that many countries with the highest scoring students on achievement tests such as Japan, Denmark and Czech Republic, have teachers who assign little homework. Meanwhile, countries such as Greece, Thailand and Iran where students have some of the worst average scores; there are teachers who assign a lot of homework ${ }^{(12)}$.

Table 2. Percentage of children and parents' response to "nature of homework".

\begin{tabular}{lcc}
\hline Highest responses for homework & Parent $(\mathrm{n}=260)$ & Children $(\mathrm{n}=260)$ \\
\hline Given for regular practice & 35.8 & 33.5 \\
Given every night & 53.5 & 54.6 \\
About right amount & 79.6 & 78.5 \\
Neither easy nor hard & 60.8 & 51.9 \\
Always/mostly completed & 80.0 & 71.2 \\
\hline
\end{tabular}

In addition to quantity, the present study further advocates for the quality of homework. Table 3 shows that an average percentage of parents and children (55.0 and 51.1) found homework as interesting, but fewer percentage (25.4 and 31.9) found homework as challenging. However, parental support in terms of helping and reminding for both the groups indicated lower percentage of parental involvement. Likewise, more than $50 \%$ parents and children agreed favorably about parental nagging for homework and higher percentage of both the groups responded against parental conflict over homework. This finding is inconsistent with the findings of Bennett and Nancy ${ }^{(13)}$. 
The study found significant grade difference in children (Chi square $=39.520, \mathrm{df}=8, \mathrm{p}$ $<0.05$ ) and parents' responses (Chi square $=35.314, \mathrm{df}=8, \mathrm{p}<0.05$ ) to parental help shows gradual decrease with grades. Pomerantz et al. found that mothers' positive affect in the homework context buffered children's motivational and emotional functioning against mothers' negative affect as well as children's helplessness ${ }^{(14)}$. Therefore, to make significant gain in achievement schools should encourage parents to involve with children to practice reading at home ${ }^{(15)}$.

Both parental and children's response regarding reward and punishment for homework (Table 3) show that though higher percentage of both groups responded positively for punishment but positive behavior in terms of giving reward was also low. Significant grade difference in response of children (Chi square $=21.146, \mathrm{df}=8, \mathrm{p}<0.05$ ) shows a gradual decrease of reward with upper grades that may have correspondence with gradual lowering of test scores. This may reflect an impact of consequence of reward on school results. Miller and Kelley demonstrated favorable effects of reinforcing parental interaction on learning and student achievement ${ }^{(16)}$. As assumed, though extrinsic motivation is favored, yet with higher grades intrinsic motivation become more dominant. Positive parenting may be a mediating factor and thus increase awareness and training in positive parenting may have more beneficial impact of homework(7). Further analysis showed 'gift' as the most preferred choice of reward for both the groups while physical punishment was less frequent chosen means of punishment. Significant grade differences were also noted in type of reward for both the groups (Children: Chi square $=$ 32.174, $\mathrm{df}=8, \mathrm{p}<0.05 ;$ Parent : Chi square $=19.294, \mathrm{df}=8, \mathrm{p}<0.05)$.

Table 3. Response (\%) on affective and parental factor for parents and children.

\begin{tabular}{llcc}
\hline Affective and parental factors & Parents & Children \\
\hline Affective aspect & Always/frequently interesting & 55.0 & 51.1 \\
& Always/frequently challenging & 25.4 & 31.9 \\
& Never/occasionally boring & 65.4 & 65.8 \\
& Children never/occasionally get upset & 75.4 & 70.0 \\
Parental support & Always/frequently help & 28.3 & 18.0 \\
& Always/frequently Remind & 31.9 & 21.9 \\
& Never/occasionally Nag & 55.0 & 69.6 \\
Parental sonflict & Parent never/occasionally get upset & 74.7 & 77.3 \\
& Never/occasionally argument & 79.2 & 82.3 \\
Consequence of & Never/occasionally fight & 88.9 & 85.8 \\
homework & Frequently/always rewarded & 17.0 & 15.4 \\
& Never/occasionally punished & 80.8 & 81.5 \\
\hline
\end{tabular}

The study found significant gender differences among children on certain study variables. Greater percentage of boys (25) than girls (4.1) said that homework is given for 
better learning and development (Chi square $=24.835, \mathrm{df}=4, \mathrm{p}<0.05)$. Similarly, more boys find homework harder than girls (Chi square $=15.657, \mathrm{df}=4, \mathrm{p}<0.05)$ and get more upset about homework (Chi square $=9.777, \mathrm{df}=4, \mathrm{p}<0.05)$. This finding may be reflective of social perception of gender roles where boys are preferred to play more active and productive functions.

Certain variables were, also significantly correlated with 'liking for school'. Table 4 shows that favorable attitude towards homework has positive correlation with favorable attitude towards school. Therefore, teachers and school authority would take proper planning and designing of homework into consideration to make school experience favorable.

Table 4. Mean (Sd) with r value correlating "liking for school".

\begin{tabular}{lll}
\hline Factors & Mean (SD) & r value \\
\hline Homework is interesting & $3.69(1.032)$ & $\mathrm{r}=0.331^{*}$ \\
Homework is never boring & $3.90(0.939)$ & $\mathrm{r}=0.307^{*}$ \\
No arguments at home & $4.41(0.831)$ & $\mathrm{r}=0.285^{*}$ \\
No fights at home & $4.48(0.808)$ & $\mathrm{r}=0.276^{*}$ \\
Never child upset for homework & $3.97(0.917)$ & $\mathrm{r}=0.308^{*}$ \\
Never refuse homework & $4.27(0.855)$ & $\mathrm{r}=0.286^{*}$ \\
\hline
\end{tabular}

*Significant at 0.01 level.

The study recommends that parents, teachers, and children need to recognize the substantial worth of out of school homework on improved academic achievement as suggested by Keith et al.(17). Authority should develop age appropriate policy and guidelines to structure homework purposefully and interestingly to reduce its burden and maximize benefits for the children. While assigning homework, focus should be on the creativity of students rather than rote memorization or just copying from the book.

In general both parent and children had a favorable attitude towards homework with positive impact on preferring school and school performance. The study highlighted the importance of designing lesson plan to monitor the quality and quantity of homework and effective parental involvement. This study will have indirect impact on national education as well as foster joyful learning and meaningful growth.

\section{Acknowledgement}

This research was supported in part by grants from Center for Advanced Studies and Research in Biological Science, University of Dhaka, Bangladesh.

\section{References}

1. Cooper H 1989. Homework. White Plains, N. Y., Longman. 
2. Gill BP and SL Schlossman 2000. The lost cause of homework reform. American J. Edu. 109: 27-62.

3. Eagly A and S Chaiken 1993. The psychology of attitudes. Fort Worth, TX: Harcourt Brace Jovanovich.

4. Marzano RJ and DJ Pickering 2007. Special topic/the case for and against homework. Educational Leadership. 64(6): 74-79.

5. Duke Study: Homework helps students succeed in school, as long as there isn't too much. 2006. Retrieved from http://dukenews.duke.edu/2006/03/homework.html

6. Goldstein S and SS Zentall 1999. Seven steps to homework success: A family guide for solving common homework problems. Specialty Press, Inc. Retrieved from http://www.hi2u.org/ adhd/homework_1.htm

7. Hill NE and DF Tyson 2009. Parental involvement in middle school: A meta-analytic assessment of the strategies that promote achievement. Developmental Psychology. 45(3): 740-763. Doi: 10.1037/a0015362.

8. Xu J 2011. Homework completion at the secondary school level: A multi-level analysis. J. Edu. Research. 104(3):171-182. Doi: 10.1080/00220671003636752.

9. Hancock DR 2000. Impact of verbal praise on college students' time spent on homework. J. Edu. Research. 93(6): 384-389. Doi: 10.1080/00220670009598733.

10. Gilmore L 2007. Homework: A necessary evil? Paper presented at the APS Annual Conference, Brisbane.

11. Easton J and A Bennett 1990. Achievement effects of homework in sixth grade classrooms. Paper presented at the Annual Meeting of the American Educational Research Association. 320675. Retrieved from http://www.whatsfordinner.net/articles/article-Whatis-the-Value-of- Homework2.html.

12. Baker DP and GK LeTendre 2005. National differences, global similarities: World culture and the future of schooling. Stanford University Press.

13. Bennett $S$ and K Nancy 2006. The case against homework: How homework is hurting our children and what we can do about it. P.60. New York: Crown Publishers.

14. Pomerantz EM, Q Wang and FFY Ng 2005. Mothers' affect in the homework context: The importance of staying positive. Developmental Psychology 41(2): 414-427. Doi: 10.1037/ 0012-1649.41.2.414.

15. Tizard J, WN Schofield and I Hewison 1982. Collaboration between teachers and parents in assisting children's reading.

16. Miller DI and ML Kelley 1991.Interventions for improving homework performance: A critical review. School Psychology Quarterly. 6(3): 174-185. Doi: 10.1037/h0088812.

17. Keith TZ, C Diamond-Hallam and JG Fine 2004. Longitudinal effects of in-school and out-ofschool homework on high school grades. School Psychology Quarterly. 19(3): 187-211. Doi: 10.1521/scpq.19.3.187.40278. 